\title{
EXAMINATION OF MICRO VASCULAR DENSITY ON METASTATIC COLORECTAL CANCER OF RAS MUTANT-TYPE AS ANTI VEGF THERAPY PREDICTOR
}

\author{
Heru Sulistyo ${ }^{1}$, Vicky Sumarki Budipramana ${ }^{2}$ \\ ${ }^{1}$ Specialist Doctor Education Program (PPDS-II) Digestive Surgery, Faculty of Medicine, Universitas \\ Airlangga/Dr. Soetomo General Academic Hospital, Surabaya, Indonesia \\ ${ }^{2}$ SMF/Lab Digestive Surgery, Surgery Science, Faculty of Medicine, Universitas Airlangga/Dr. Soetomo General \\ Academic Hospital, Surabaya, Indonesia
}

\section{ABSTRACT}

\begin{abstract}
According to the NCCN Clinical Practice Guidelines in Oncology (NCCN Guidelines) on Colon Cancer Version 2.2019, mCRC patients with mutant type RAS were treated with anti-VEGF. However, the use of the targeting therapy still had inconsistent results. Neoangiogenesis studies had been used as a basis to assess the prognosis of mCRC. Micro vascular density (MVD) had become morphological gold standard for assessing neovascularization in human tumors. This study proved the existence of low micro vascular density (MVD) in mCRC patients with mutant type RAS status as a predictor of failure of anti VEGF therapy. There were 29 patients at Dr. Soetomo Academic Hospital from 2015-2018 who had their RAS status checked and tested for microvascular density (MVD). The results of this study were analyzed using SPSS 23.0. In the Mutant-type of RAS group, micro vascular density (MVD) was examined. It was found that 11 (73\%) research subjects had high MVD scores and 4 (27\%) research subjects had low MVD scores. It was found that 27\% micro vascular density (MVD) was low, in the mutant-type of RAS $m C R C$ patient which could be used as a predictor factor for the failure of anti-VEGF therapy.
\end{abstract}

Keywords: metastatic colorectal cancer; microvascular density; RAS mutant-type; bevacizumab

\section{ABSTRAK}

Menurut NCCN Clinical Practice Guidelines in Oncology (NCCN Guidelines) Colon Cancer Version 2.2019, pasien mCRC dengan RAS tipe mutant diterapi dengan anti VEGF. Akan tetapi, hingga saat ini penggunaan targeting terapi tersebut masih mempunyai hasil yang inkonsisten. Pemeriksaan neoangiogenesis telah dijadikan sebagai dasar untuk menilai prognosis dari mCRC. Micro vascular density (MVD) telah menjadi standar baku emas secara morfologis untuk menilai neovaskularisasi pada tumor manusia. Membuktikan adanya micro vascular density (MVD) yang rendah pada pasien mCRC dengan status RAS tipe mutant sebagai prediktor kegagalan terapi anti VEGF. 29 pasien di RSUD Dr. Soetomo dari tahun 2015-2018 yang telah dilakukan pemeriksaan RAS status kemudian dilakukan pemeriksaan microvascular density (MVD). Hasil dianalisis dengan SPSS 23.0. Pada kelompok RAS tipe Mutan, dilakukan pemeriksaan micro vascular density (MVD). Didapatkan hasil 11 (73\%) subjek penelitian mempunyai nilai MVD yang high dan 4 (27\%) subjek penelitian mempunyai nilai MVD yang low. Didapatkan $27 \%$ micro vascular density (MVD) yang rendah, pada pasien mCRC RAS Tipe Mutan yang dapat digunakan sebagai faktor prediktor kegagalan terapi anti VEGF.

Kata kunci: metastatic colorectal cancer; microvascular density; RAS tipe mutan; bevacizumab

Correspondence: Vicky Sumarki Budipramana, SMF/Lab Digestive Surgery, Surgery Science, Faculty of Medicine, Universitas Airlangga/Dr. Soetomo General Academic Hospital, Surabaya, Indonesia. Email: vicky.sumarki@fk.unair.ac.id

pISSN:2355-8393 • eISSN: 2599-056x • doi: 10.20473/fmi.v57i2.18249

- Fol Med Indones. 2021;57:111-116 • Received 13 Mar 2020 • Accepted 04 Jun 2020

- Open access under CC-BY-NC-SA license • Available at https://e-journal.unair.ac.id/FMI/ 


\section{INTRODUCTION}

Metastatic colorectal cancer (mCRC) is one of the leading causes of cancer death in the worldwide. According to the NCCN Clinical Practice Guidelines in Oncology (NCCN Guidelines) Colon Cancer Version 2.2019, current therapy for mCRC patients can use chemotherapy and therapeutic targeting. Therapeutic targeting is given based on the RAS status. Bevacizumab is administered in the mutant-type RAS. Yet until now, the targeting therapy still has inconsistent results.

Several studies have tried to investigate the effect of targeting therapy for patients with $\mathrm{mCRC}$; one of which is the anti-VEGF administration. In a meta-analysis study by Baraniskin et al (2018) stated that giving antiVEGF to mCRC patients (Bevacizumab) did not affect Overall Survival (OS) compared to mCRC patients who were not given Bevacizumab therapy. This finding can be a detrimental to mCRC sufferers, because mCRC had an average doubling time of 3 months (Sugarbaker 2014). Therefore, when mCRC does not respond well to Bevacizumab, then mCRC sufferers can lose its window period which can be used for administration with other types of therapy.

Currently, neoangiogenesis has been used as a basis for assessing the prognosis of mCRC. Neoangiogenesis can be assessed from micro vascular density (MVD) (Chabowski et al 2018, Grivas et al 2016). MVD is a measure of tumor neoangiogenesis and a significant prognostic factor correlated with an increased probability of metastasis and a worse prognosis in many tumor types, including mCRC (El Sabaa et al 2012). According to a study by Liang et al (2004), and Anannamcharoen and Nimmanon (2012), MVD has a better prognostic value than VEGF in assessing angiogenesis on mCRC. MVD has become morphological gold standard for assessing neovascularization in human tumors (Nico et al 2008).

Bevacizumab is an anti-VEGF agent which acts as a therapeutic targeting by inhibiting vascularity (KazaziHyseni 2010). The higher the vascularity of a cancer, the better the work of Bevacizumab, so that the MVD examination is expected to be used as a predictor of mCRC therapy using anti-VEGF therapy targeting, because the predictive biomarker of bevacizumab therapy has not been clearly identified until now (Chen et al 2019).

Bevacizumab therapy gives a varied response, because the neoangiogenesis of each tumor does not all have a high MVD value. We hoped that MVD in mCRC patients with mutant-type RAS could be used as a predictive factor for the failure of anti-VEGF therapy. Based on these premises, we conducted a study on neoangiogenesis (micro vascular density) in mCRCs RAS mutant-type using CD31 as a marker of MVD.

\section{MATERIALS AND METHODS}

This study used cross sectional analytic method to prove the existence of low micro vascular density (MVD) in mCRC patients with RAS mutant-type status at Dr. Soetomo General Academic Hospital in 2015-2018 who predictably did not respond to anti-VEGF therapy. The study population was all metastatic colorectal cancer (mCRC) patients who had undergone a RAS status examination at Dr. Soetomo General Academic Hospital Surabaya.

The study sample was all patients with metastatic colorectal cancer (mCRC) who had their RAS status checked at Dr. Soetomo General Academic Surabaya from 2015-2018 who met the inclusion and exclusion criteria with a total sampling technique. Data on metastatic colorectal cancer (mCRC) patients who met the inclusion and exclusion criteria were recorded and collected from 2015-2018. The research data included name, age, gender, anatomical location of colon cancer, examination of RAS status to determine the type of gene mutation and wild type or mutant type. Then, this study measured MVD levels in the patient's paraffin block network. Data management was carried out using SPSS 23.0 program. The data were presented in the form of a frequency distribution table and cross tabulation.

\section{RESULTS}

This study used a cross sectional analytic method to prove the existence of a low micro vascular density (MVD) in mCRC patients with mutant type status at Dr. Soetomo Academic Hospital, so that it could be a consideration in administering anti VEGF therapy in mCRC RAS mutant type. In this study, the study subjects were all metastatic colorectal cancer (mCRC) patients whose RAS status was examined at Dr. Soetomo Academic Hospital Surabaya from 2015 to 2018 where the exclusion was carried out in patients with mCRC cancer whose paraffin blocks were not found and in Paraffin block patients with mCRC cancer whose tumors had again been found.

The variable was the micro vascular density (MVD) taken from the paraffin block of patients with metastatic colorectal cancer (mCRC) from 2015 to 2018 at the 
Department of Pathology, Anatomy, Dr. Soetomo General Academic Hospital Surabaya.

\begin{tabular}{ll}
\hline Variable & Statistical Description \\
\hline RAS Type & RAS Wild-Type: $14(48 \%)$ \\
& RAS Mutant-Type: $15(52 \%)$ \\
\hline
\end{tabular}

Table 1. Characteristics of type RAS

Table 2. Demographic characteristics of the mutant RAS group

\begin{tabular}{llcc}
\hline Variable & Statistical Description & Amount & Total \\
\hline \multirow{3}{*}{ Gender } & Man & 5 & $33 \%$ \\
& Women & 10 & $10.67 \%$ \\
& & & $15100 \%$ \\
Age & Mean: 52 years & & \\
& Min: 31 years & SD: 11.5 & - \\
Lax: 71 years & & \\
Cancer Anation of Colorectal & Right Colorectal Cancer & 11 & $73 \%$ \\
& Left Colorectal Cancer & 4 & $27 \%$ \\
\hline
\end{tabular}

\section{Gender of Mutant}

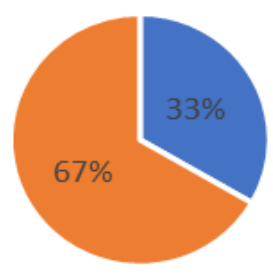

- $\mathrm{L}$ - $\mathrm{P}$

Figure 1. Subject gender diagram

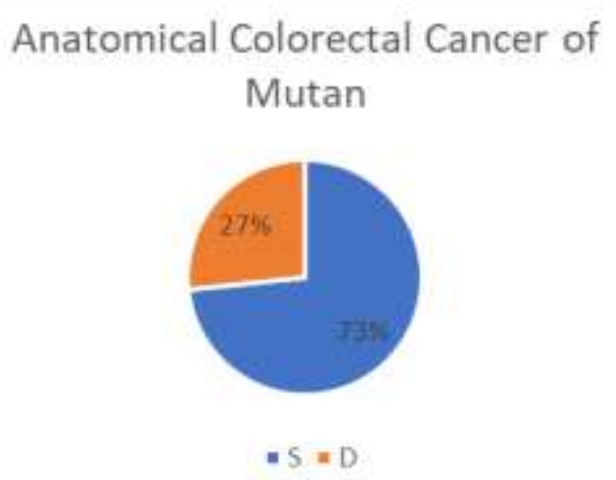

Figure 2. Diagram of the subject's anatomical colorectal cancer

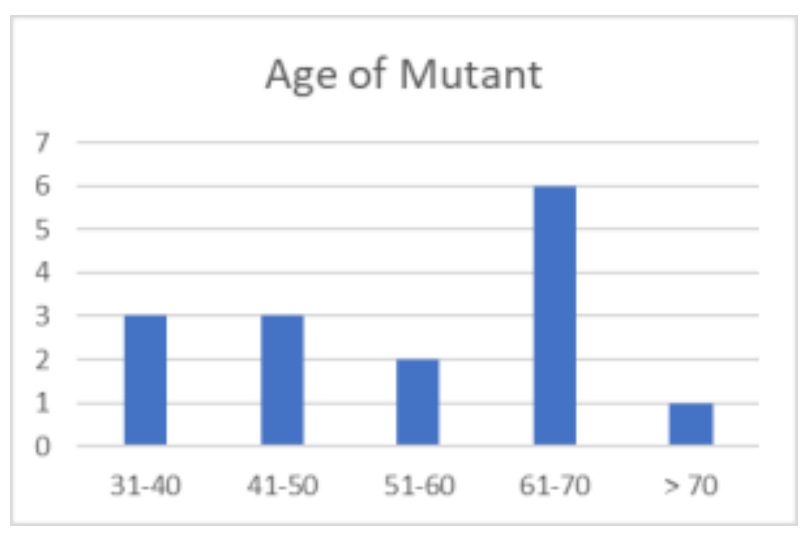

Figure 3. Diagram of subject age (RAS mutant)

Based on the data above, most of the samples in this study. Subjects of this study were found 15 people with RAS mutants consisting of 5 males and 10 females. In this study, it was also found that the age of the oldest subject was 71 years and the youngest subject was 31 years old with an average age of 52 years. Besides, this study also found that there were 11 study subjects who had colorectal cancer on the right and 4 study subjects had colorectal cancer on the left. It was also found that 15 research subjects had mutant-type RAS and 14 subjects had wild-type RAS.

This study also aimed to prove the existence of a low micro vascular density (MVD) in mCRC patients with mutant type status at Dr. Soetomo General Academic Hospital which could be considered in administering anti-VEGF therapy. In this study, 15 research subjects 
with mCRC had a RAS mutant-type. In the RAS group of the mutant type, micro vascular density (MVD) was examined and resulted that 11 study subjects had high MVD values with a presentation of $73 \%$ of the total subjects. It was also found that 4 research subjects had low MVD scores with a presentation of $27 \%$ of the total subjects.

Table 3. Data statistic of mutant type MVD RAS

\begin{tabular}{ll}
\hline Mutant Type MVD RAS & Total \\
\hline High & $11(73 \%)$ \\
Low & $4(27 \%)$ \\
\hline
\end{tabular}

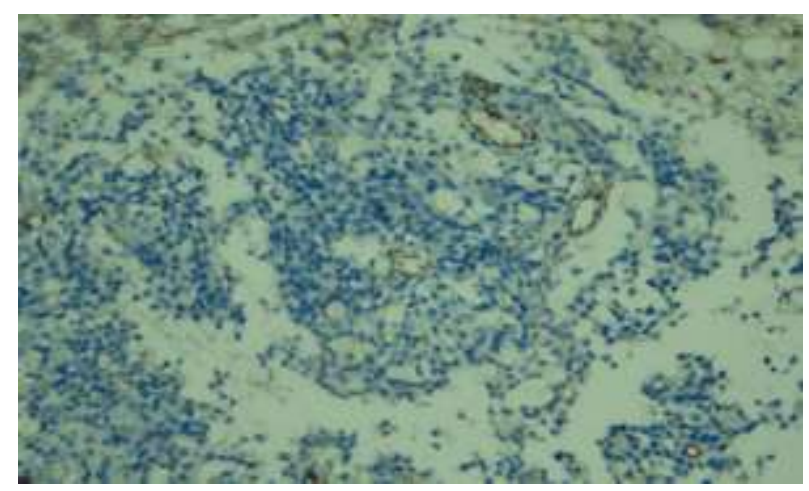

Figure 4. Microscopic overview of MVD low with 200x magnification

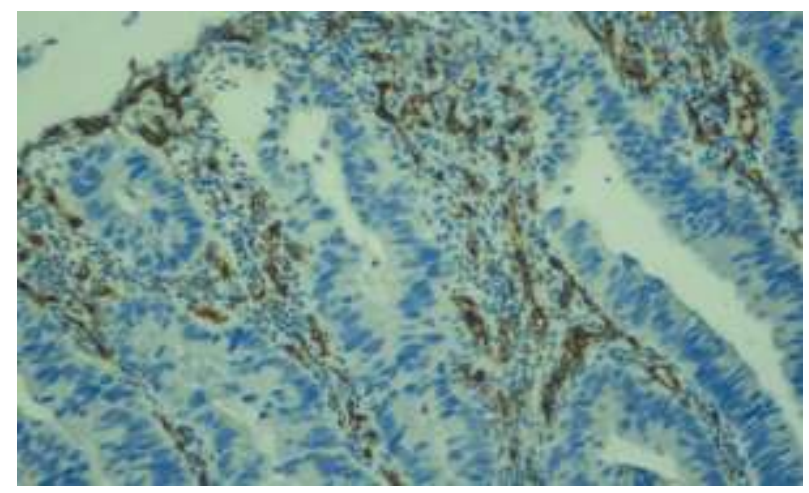

Figure 5. Microscopic image of MVD high with 200x magnification

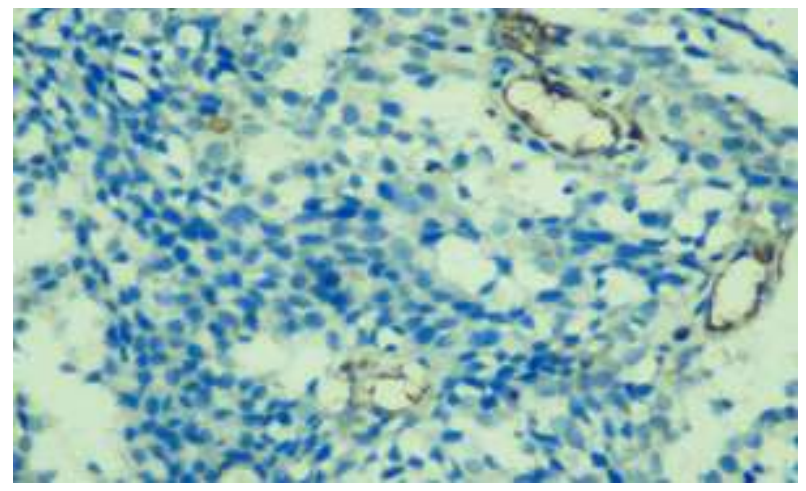

Figure 6. Microscopic overview of MVD low with 400x magnification

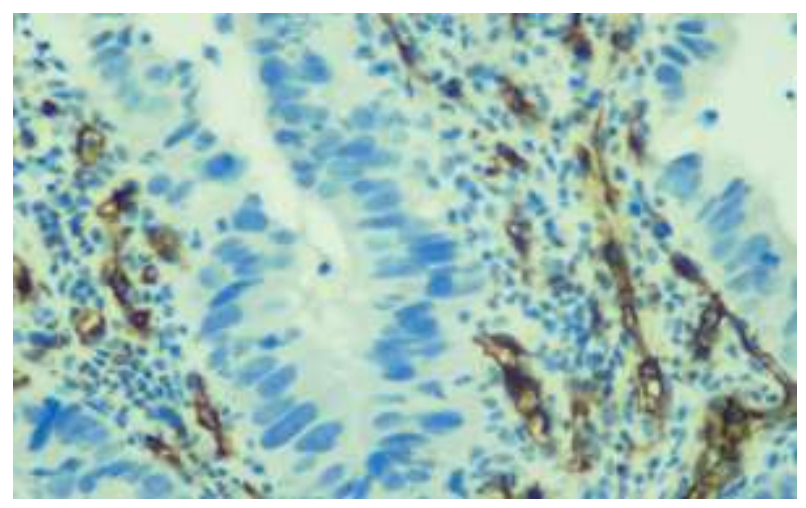

Figure 7. Microscopic image of MVD high with 400x magnification

\section{DISCUSSION}

This study used cross sectional analytic method that could prove the existence of low micro vascular density (MVD) in mCRC patients with mutant type status at Dr. Soetomo General Academic Hospital. This could be a consideration in providing therapy in the mCRC RAS mutant-type with low MVD. In this study, the study subjects included were all metastatic colorectal cancer (mCRC) patients whose RAS status was examined at Dr. Soetomo General Academic Hospital Surabaya from 2015 to 2018 where the exclusion of patients with colorectal cancer was not found; or had no paraffin block found anymore.

Metastatic colorectal cancer (mCRC) was one of the leading causes of cancer death in the worldwide (Rumpold et al 2020, Rawla et al 2019). According to the NCCN Clinical Practice Guidelines in Oncology (NCCN Guidelines) Colon Cancer Version 2.2019, the current therapy for mCRC patients could use chemotherapy and therapeutic targeting (NCCN 2019). Therapeutic targeting was given based on the RAS 
status. The administration of Bevacizumab could be done in both wild and mutant RAS. However, the targeting therapy has had inconsistent results with the administration of bevacizumab up to now.

Several studies had tried to investigate the effect of targeting therapy for patients with mCRC; one of which was the anti-VEGF administration. In a meta-analysis study by Baraniskin et al (2019), giving anti-VEGF (Bevacizumab) to mCRC patients did not affect Overall Survival (OS) compared to mCRC patients who were not given Bevacizumab therapy. This finding could be detrimental to mCRC sufferers, because it had an average doubling time of 3 months (Sugarbaker 2014). Therefore, when mCRC did not respond well to Bevacizumab, mCRC could lose the window period that could be used for administration with other types of therapy.

In this study, it was found that there were 15 research subjects who had a mutant type of RAS and 14 subjects were found to have a wild type of RAS from a total of 29 research subjects. Cercek (2017) had found that $68 \%$ of the research subjects had a mutant type of RAS and $32 \%$ had a wild type of RAS. It indicated a similarity in the prevalence of the RAS type with this study. In addition, the higher number of mCRCs RAS mutanttype in its prevalence than mCRC RAS wild-type, so that the management of mCRCs with RAS mutant-type was considered important for optimal management.

Bevacizumab is a monoclonal antibody that works by neutralizing VEGF-A, so that it can inhibit the vascularization of cancer cells ( $\mathrm{Yu}$ et al 2010). In several studies, the search for markers and predictor factors has been carried out in assessing the use of Bevacizumab therapy. A study in the United States involved VEGF-A, proteinuria and hypertension to be studied for their ability to be predictor factors of Bevacizumab therapy; yet, there was still no definite predictor factor that could be used in therapy using Bevacizumab on mCRC until now (Sujindra \& Bupathy 2016).

MVD is a measure of tumor neoangiogenesis and a significant prognostic factor correlated with an increased likelihood of metastasis and a worse prognosis in many tumor types, including mCRC (El Sabaa et al 2012). A study by Liang et al (2004) and Anannamcharoen and Nimmanon (2012) had proven that MVD had a better prognostic value than VEGF in assessing angiogenesis on mCRC. MVD had become the morphological gold standard to assess neovascularization in human tumors (Nico et al 2008).
Apart from focusing on mCRCs patients in RAS mutant-type, this study also aimed to prove the existence of a low micro vascular density (MVD) in mCRC patients with mutant type status at Dr. Soetomo General Academic Hospital, so that it could be a consideration in administering Bevacizumab therapy mCRC RAS mutant type. This study found that 11 $(73 \%)$ of the mCRCs with mutant-type RAS had high MVD and $4(27 \%)$ of the mCRCs with RAS mutanttype had low MVD. It indicated that 27 percent of mCRCs with RAS mutant-type were likely to undergo a failure in treatment with Bevacizumab.

By knowing the possibility of failure of therapy with Bevacizumab, it was possible to immediately change the therapy regimen on the $\mathrm{mCRC}$. A replacement therapy (e.g., Regorafenib) could be used, so that the mCRC sufferer did not lose the adverse window period. It was expected that in the future, microvessel density (MVD) can be used as a predictor of failure of Bevacizumab therapy, so that the handling of mCRC with RAS mutant-type can be more optimal.

\section{CONCLUSION}

This study could imply that a study with a larger and multicentre sample scale was needed. Anti-VEGF therapy in the mCRC mutant-type should be considered, because 27\% had low MVD. If the MVD was low, it was necessary to consider Regorafenib therapy or immunotherapy in order that the mCRC sufferer did not lose the window period.

\section{REFERENCES}

Anannamcharoen S, Nimmanon T (2012). Study of the vascular endothelial growth factor (VEGF) expression and microvascular density (MVD) in primary colorectal cancer specimens. J Med Assoc Thai 95, 1041-7.

Baraniskin A, Buchberger B, Pox C, et al (2019). Efficacy of bevacizumab in first-line treatment of metastatic colorectal cancer: a systematic review and meta-analysis. Eur. J. Cancer 106, 37-44.

Cercek A, Braghiroli MI, Chou JF, et al (2017). Clinical features and outcomes of patients with colorectal cancers harboring NRAS mutations. Clin Cancer Res 23, 4753-4760.

Chen D, Gu K, Wang H (2019). Optimizing sequential treatment with anti-EGFR and VEGF $\mathrm{mAb}$ in metastatic colorectal cancer: Current results and controversies. Cancer Manag Res 11, 1705-1716.

Chabowski M, Nowak A, Grzegrzolka J, et al (2018). Comparison of microvessel density using nestin and 
CD34 in colorectal cancer. Anticancer Research 38, 3889-3895.

El Sabaa BM, Meleiss M, Zaki I (2012). VEGF expression and microvascular density in relation to high-risk-HPV infection in cervical carcinoma - An immunohistochemical study. Alexandria Journal of Medicine 48, 47-57.

Grivas N, Goussia A, Stefanou D, et al (2016). Microvascular density and immune histochemical expression of VEGF, VEGFR-1 and VEGFR-2 in benign prostatic hyperplasia, high-grade prostate intraepithelial neoplasia and prostate cancer 69, 63-71.

Kazazi-Hyseni F, Beijnen JH, Schellens JHM (2010). Bevacizumab. Oncologist 15, 819-825.

Liang JT, Huang KC, Jeng YM, et al (2004). Microvessel density, cyclo-oxygenase 2 expression, $\mathrm{K}$-ras mutation and p53 overexpression in colonic cancer. Br J Surg 91, 355-361.

NCCN Foundation (2019). Colon cancer, NCCN Foundation, Inc, United States, p 1-88.
Rawla P, Sunkara T, Barsouk A (2019). Epidemiology of colorectal cancer: incidence, mortality, survival, and risk factors. Prz Gastroenterol 14, 89-103.

Rumpold H, Niedersüß-Beke D, Heiler C, et al (2020). Prediction of mortality in metastatic colorectal cancer in a real-life population: a multicenter explorative analysis. BMC Cancer 20, 1-9.

Sugarbaker PH (2014). Update on the prevention of local recurrence and peritoneal metastases in patients with colorectal cancer. World J Gastroenterol 20, 9286-9291.

Sujindra E, Bupathy A (2016). Adolescents friendly health services: Perceptions and practice of medical professionals. International Journal of Reproduction, Contraception, Obstetrics and Gynecology 5, 29682972.

Yu Y, Lee P, Ke Y, et al (2010). A humanized antiVEGF rabbit monoclonal antibody inhibits angiogenesis and blocks tumor growth in xenograft models. PLOS ONE 5, 1-12. 